\title{
Sustainable market valuation of buildings by the single-valued neutrosophic MAMVA method
}

\author{
Edmundas Kazimieras Zavadskas ${ }^{\mathrm{a}, *}$, Romualdas Bausys ${ }^{\mathrm{b}}$, Arturas Kaklauskas ${ }^{\mathrm{c}}$, \\ Ieva Ubarte ${ }^{\mathrm{d}}$, Agne Kuzminske ${ }^{\mathrm{d}}$, Neringa Gudiene ${ }^{\mathrm{c}}$ \\ a Department of Construction Technology and Management, Faculty of Civil Engineering, Vilnius Gediminas Technical University, Sauletekio Ave. 11, \\ LT-10223, Lithuania \\ ${ }^{\mathrm{b}}$ Department of Graphical Systems, Faculty of Fundamental Sciences, Vilnius Gediminas Technical University, Sauletekio Ave. 11, LT-10223, Lithuania \\ c Department of Construction Economics and Property Management, Faculty of Civil Sciences, Vilnius Gediminas Technical University, Sauletekio Ave. 11, \\ LT-10223, Lithuania \\ ${ }^{\mathrm{d}}$ Research Institute of Smart Building Technologies, Faculty of Civil Engineering, Vilnius Gediminas Technical University, Sauletekio Ave. 11, LT-10223, \\ Lithuania
}

\section{A R T I C L E I N F O}

\section{Article history:}

Received 29 November 2016

Received in revised form 7 March 2017

Accepted 25 March 2017

Available online 31 March 2017

\section{Keywords:}

Real estate

Market value assessment

MCDM

Neutrosophic set

MAMVA method

\begin{abstract}
A B S T R A C T
Traditionally, the real estate asset assessment is performed by experienced valuators, who take into account its economic, social, physical and locational aspects. Nowadays, the construction industry is becoming more and more influenced by the sustainability requirements. Therefore, the inclusion of the sustainability evaluation into real estate asset valuation is of utmost importance. The Neutrosophic MultiAttribute Market Value Assessment (MAMVA) method developed by the authors of this article handles market value calculations by solving multiple criteria assessment problems, and the initial information vagueness is modelled explicitly. The supplementary novelty of the present paper is the inclusion of the sustainability aspects into the real estate market valuation. The sustainable market valuation of Croydon University Hospital (Emergency Department) is performed as the case study to present numerical capabilities of the proposed approach. Our research findings suggest that neutrosophic MAMVA is a rational approach for calculations of property market valuation and might be suitable for application worldwide.
\end{abstract}

(c) 2017 Elsevier B.V. All rights reserved.

\section{Introduction}

Real estate valuation is one of the most significant problems for the various socio-economic stakeholders. Traditionally, this problem is considered as the evaluations performed by the skilled experts, which decisions are governed by their rich experience. Nowadays the researchers put a lot of the efforts to reconstruct this valuation process into a more objective and mathematically stricter approach. Various valuation aspects are considered in Refs. [1-4]. Individual scientists and practitioners throughout the world employ cost for calculating market values in real estate $[5,6]$. Some of them use sales comparisons [7-11]. Still, others take the approaches of income [6]. But only a few multiple criteria decision making [12-14] methods are used for that purpose. The classical

\footnotetext{
* Corresponding author.

E-mail addresses: edmundas.zavadskas@vgtu.lt

(E.K. Zavadskas), romualdas.bausys@vgtu.It (R. Bausys), arturas.kaklauskas@vgtu.It (A. Kaklauskas), ieva.ubarte@vgtu.lt (I. Ubarte), agne.kuzminske@vgtu.lt

(A. Kuzminske), neringa.gudiene@vgtu.lt (N. Gudiene).
}

valuation approaches do not take into account the consideration the weights of the criteria and cannot produce a single optimal market value because valuations are opinions and differ with the valuator. On the other hand, it is necessary to include the real estate asset's predicted performance and the rated sustainability aspects. Originally, market valuation approach, namely MAMVA (Multi-Attribute Market Value Assessment) was developed to estimate market values of the building life cycle project alternatives and renovation projects [13] and applied later [14]. This method is based on market value calculations by solving multiple criteria assessment problems with prior assessment of property expert's preferences used and the weights and values of assessment criteria taken into account. This approach was designed to deal with crisp information; therefore this method cannot consider the vagueness of the valuator opinions.

We recommend the novel augmentation form of MAMVA method, specifically MAMVA-SVNS. This approach is composed under neutrosophic set environment, and vagueness of the initial information is modelled in the explicit form. The inclusion of the performance and sustainability aspects of the valuated real 
estate asset is founded on Building Research Establishment Environmental Assessment Method (BREEAM). This approach is one of the most commonly used performances rating systems for the real estate assets. Aggregating the neutrosophic MAMVA method with Building Research Establishment Environmental Assessment Method (BREEAM) approach enables us to perform the real estate asset valuation incorporating the sustainability aspects.

The purpose of this paper is to propose the new extension market valuation method MAMVA, which can incorporate the assessment of multi-criteria building performance system and can process vague initial information under environment of the neutrosophic sets.

This paper has the following organization: In Section 2 the literature review dedicated to the considered problem is produced, Section 3 the general procedure of the real estate asset market valuation applying the proposed neutrosophic MAMVA method is presented, Section 4 further describes specific aspects of the neutrosophic market valuation method, in Section 5 the market valuation results of Croydon University Hospital (Emergency Department) are presented, in Section 6 comparison of calculated BREEAM and MAMVA scores are shown and at last in Section 7 we conclude the results.

\section{Literature review}

The researchers have been proposed a lot of the different techniques for the modelling of the real estate asset valuation and the solution procedures. Kettania and Oral [15] applied the analogical regression model for a market value appraisal. The paper dealt with the estimation of the market value of the real estate asset under consideration using sale comparison approach. Cupal [16] explained the factors influencing the market price (market value) in the area of the real estate market, property valuation including statistical models. Many important market factors may cause the market value of property to deviate from its real value significantly. The author applied different statistical approaches: ANOVA, Friedman test (Friedman ANOVA) and Distance-Weighted Least Squares (DWLS).

Zujo et al. [5] proposed a simple and easily adaptable market value estimation model based on the cost approach method, which is the method most frequently applied in three ex-Yugoslavian countries. This model offers the possibility of real estate market value estimation in a short time after determining the input parameters. The data parameters are the cost of the immediate structure construction (the so-called structure construction value), land value, supply a connection value, the value of the plot surrounding the structure (if any), the value of the design and supervision service, the value of various fees (land use permit, building permit and other various fees) and estimated market factor. Moreover, the age of the structure is also one of the input parameters as well as the expected service life of the structure based on the type of depreciation value calculated.

Das [17] performed research concerning the empirical analyses of US hotels and made the conclusion that hotel capitalization rate is a composite aggregation of macroeconomic and asset class specific attributes in addition to the cost of capital, capital structure and growth rate. Ben-Shahara et al. [18] applied the Shapley value approach for determining the cost of the real estate assets as a function of the stories of a building. Ahn et al. [19] proposed a new extension of the ridge regression approach to solving real estate appraisal forecasting problem.

The sales comparison approach was employed for determining market values by Popescu et al. [7] for blocks of flats, Romenesco [8] for vacant lands and historic farm buildings, Gill and Richmond [9] for apartment buildings, Breazu et al. [10] for land plots located within a built-up area and Hawran and Malm [11] for Subject Parcel lands. Popescu et al. [7] evaluated blocks of flats. The criteria analysed to determine market value at the time of evaluation were used surface, property rights, financial conditions, market conditions, age, floor/height conditions, location and improvements like special sandstone+ tile, special front door, wood floor (natural wood) and the wasted/saved energy of a building. Gill and Richmond [8] submits an evaluation report of an apartment building. The criteria under analysis for determining the market value of an object were location, the total number of units, year built/renovated, condition/street appeal, HVAC, parking, unit amenities, project amenities and property type. Breazu et al. [10] presents an evaluation report for a plot of land located within a built-up area. The following comparison criteria were considered to determine the market value of an object by using the direct comparison method: transaction/offer, surface of the land, location, infrastructure (utilities systems, access road), shape and size (possibility to parcel out a future residential development), strengths (vecinatate forest/lake/DN vicinity, future projects, etc.), possible restrictions (network electricity, main gas pipeline, public roads (existing or under planning) and such) and building restrictions established by the regulations for urbanism (cumulative coefficients).

The estimated market value is highly related to exposure, time, promotional efforts, terms, motivation and conditions pertinent to the offering. The value estimate considers the productivity and relative physical and economic attractiveness of the property in the marketplace. An appraisal involving an estimate of market value is a reflection of its benefits and an appraiser's interpretation of income, yields and other factors derived from general and specific, client-based market information. Such estimates are thus subject to change since the market and value are naturally dynamic [9]. The market value of the real estate determined may change along with changes in the supply-demand related to the local market [8].

Murphy [6] employed cost, sales comparison and income approaches for performing the determination of the market value of a multi-tenant office building. The procedures used to estimate the property value resulted in generally similar value conclusions, exhibiting less than $15 \%$ variance. Most of the attention was on the income approach. The remaining, concluding value estimates were analogous to that determined in the income approach.

Hajnal [20] proposed to solve the real estate appraisal problem by aggregating the income-based calculation and the nontraditional methodologies. He stated that this approach could provide a reassuring result of the market value of an unfinished investment.

İslamoğlu et al. [21] performed financial analysis of REITs for the period 2011-2014 within the financial market in Turkey was measured using Entropy-based TOPSIS. Uysal and Tosun [22] implemented TODIM method to select the best residential alternative based on both objective and subjective factors. In this study, objective and subjective factors were used. This method requires the values of the evaluation, of the alternatives with the criteria, to be numerical and to be normalised; consequently, the qualitative criteria evaluated on a verbal scale are transformed into a cardinal scale.

Moshkovich et al. [12] also implemented TODIM approach for evaluation of real estate properties based on the framework for multicriteria decision-making. The performance of this process requires three phases using the TODIM, a multicriteria method. The proposal for market value estimation is an "adjusted value" iterative procedure. The final property price ensures that the overall quality of the alternative does not differ from comparable properties on the market by more than the stated threshold. Volta Redonda City of Brazil illustrates an application of this process. A comparison of the results is by the "proportional approach." The "adjusted 
value" approach showed a significant improvement compared to the "proportional" adjustment of market values.

The rental evaluation of a property is a task of primary importance for those who work in the Brazilian market for real estate [23]. Quantitative and qualitative criteria employing various simple methods serve as the basis for such an evaluation. The Comparative Method involves checking similar properties at locations close to the property in question and, based on comparisons with the data obtained, establishing the value of the rent. The real estate market practices this method the most; it frequently presents a value closest to the market value. The Income Method defines the value of the rent as a percentage of the sales value of the property. It is simple to apply, but depending on the supply and demand in the region in question; it may not generate competitive and practicable values in the market.

Decision makers usually solving the complex real-life practical problems have to face the problem of taking into account the vagueness of the initial information. Despite the fact that nowadays MCDM problems are solved applying various approaches, which are constructed implementing different fuzzy sets [24], they cannot consider all types of the information vagueness that appear in the dealing with the real decision making problems. Recently, Smarandache [25] developed a theory of the neutrosophic sets. This theory provides additional functionality to take into account "knowledge of neural thought", and this supplementary constituent brings the new possibilities to model uncertain phenomena of information. Modelling MCDM problems under the intuitionistic fuzzy set environment, the degree of the uncertainty cannot be described as independent variable, in fact, it is a function of the degree of membership and the degree of non-membership. Following neutrosophic logic, the estimate of the uncertainty degree is independent function and can be considered separately from the truth and falsity degrees. The researchers have been proposed the new extensions that are dedicated to performing under neutrosophic set environment [25-32].

\section{Market valuation by MAMVA method}

Valuation of the real estate assets is one of the most important operations in the real estate management process. Originally, the MAMVA can operate with crisp initial information, which is not the case of the modern information management techniques. Modern information management approaches allow considering various aspects of the initial information, including indeterminacy.

For the real estate asset valuation, classical sales comparison approach is employed. The conventional valuation approaches do not take into account the consideration the weights of the criteria and cannot produce a single optimal market value because valuations are opinions and differ with the valuator. On the other hand, it is necessary to include the real estate asset's predicted performance and the rated sustainability aspects. Initially, market valuation approach, namely MAMVA was developed to estimate market values of the building life cycle project alternatives and renovation projects [13] and used later [14]. This method is based on market value calculations by solving multiple criteria assessment problems with previous assessment of property expert's preferences applied and the weights and values of assessment criteria taken into account. This approach was designed to deal with crisp information; therefore this method cannot consider the vagueness of the valuator opinions.

Nowadays the sustainability criteria of the real estate assets play more and more significant role in the different evaluation processes. Consequently, it is necessary to include into valuation process the real estate asset's predicted performance and the rated sustainability aspects.
In the present paper, we propose the new broadening version of MAMVA method, specifically MAMVA-SVNS. This approach is composed under neutrosophic set environment, and vagueness of the initial information is modelled applying independent separate function of the indeterminacy. The inclusion of the performance and sustainability aspects of the valuated real estate asset is founded on Building Research Establishment Environmental Assessment Method (BREEAM). This approach is one of the most commonly used performances rating systems for the real estate assets. Aggregating the neutrosophic MAMVA method with Building Research Establishment Environmental Assessment Method (BREEAM) approach enables us to perform the real estate asset valuation incorporating the sustainability aspects.

A schematic description of the proposed neutrosophic MAMVA method follows.

First, the comparison set for market valuation of real estate asset is constructed. The real estate asset, which valuation is performed, usually takes the first place in the set. The real estate assets, which are used for the comparison, start from the second position in the set. Later, the decision making matrix is constructed, which involves evaluations of all valuation and performance parameters. The performance of assessment involves the use of various criteria based on BREEAM approach to get a comprehensive evaluation of real estate assets. This evaluation includes assessments of alternatives by the criteria considering the price, the management issues, health and wellbeing, energy, transport, water, materials, waste, land use and ecology, pollution and innovation aspects. The assessments of alternatives implicate determinations of principles regarding price significance as much as of cohesiveness.

The order of priority and utility degree for the real estate assets under investigation is calculated under the neutrosophic environment. The market value of property to be valuated is determined. If the accuracy to be achieved in computing the market value is not satisfied this means that the value of a property being valuated had not been calculated accurately enough and the approximation cycle should be repeated. In this case, the corrected value of a property being valuated is substituted into a grouped decision making matrix of property multiple criteria analysis, and the calculations should be repeated until the accuracy to be achieved. Solving the problem of determining the market value of a property being valuated, which would make it equally competitive on the market compared with the property already sold, the neutrosophic MAMVA method of defining the market value of property was suggested.

Application of this method empowers the achievement of the desired characteristics of the market valuation, such as the reliable alternative evaluation, correct system of the criteria, relevant criteria weights and so on. A detailed outline of the proposed neutrosophic MAMVA method is presented in Fig. 1.

\section{Single valued neutrosophic MAMVA method}

The MAMVA method, which was developed to establish the market valuation of building life cycle project alternatives, originally was published in [13]. Nowadays the various fuzzy approaches are becoming very popular due to they provide the possibility for the decision makers construct MCDM models, in which the vagueness of the initial information processed taking into account various aspects. Recently proposed neutrosophic sets are an abstraction of the "fuzzy" and "intuitionistic fuzzy" sets [25]. The essence of the neutrosophic sets relies on the fact that each characteristic is modelled by three variables: the degree of the truth $(\mathrm{T})$, a degree of the indeterminacy (I) and a degree of the falsity (F).

In this section, extended MAMVA method under single-valued neutrosophic set environment is presented. 


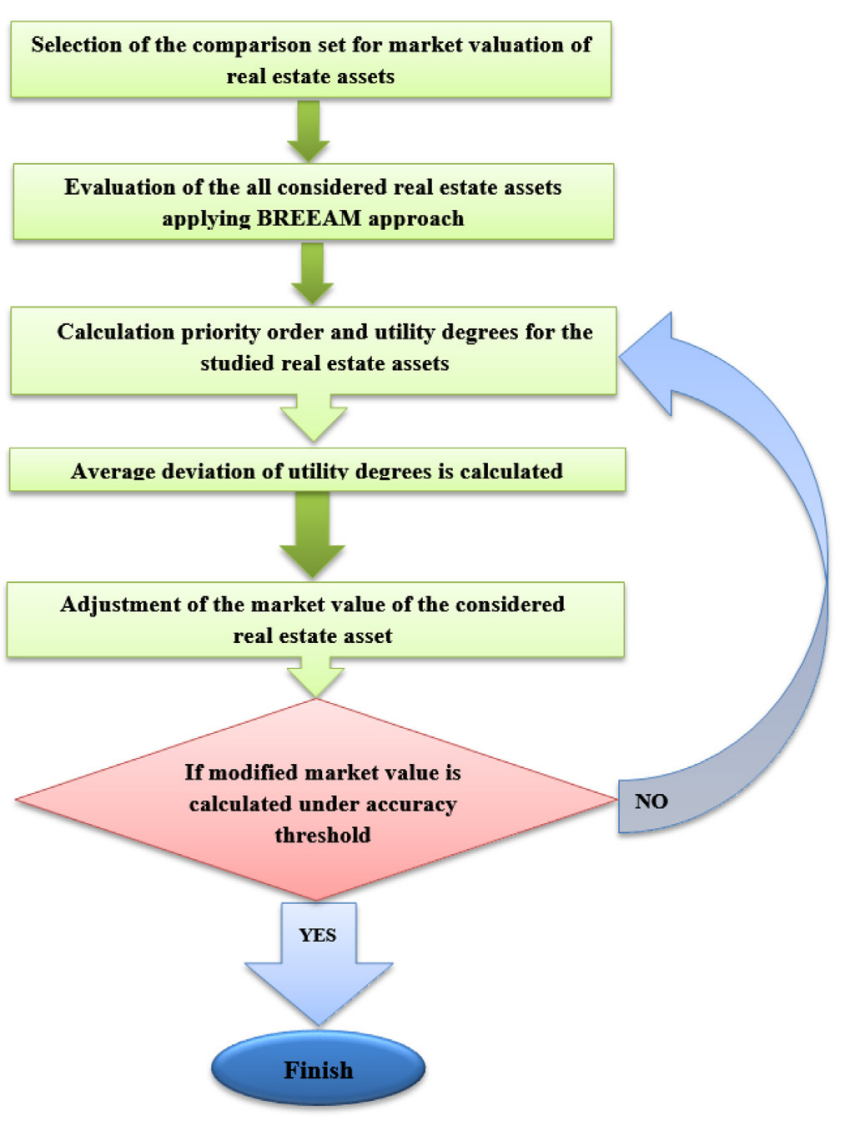

Fig. 1. Block-diagram of real estate market value estimation.

The following steps can describe the performance of the market value assessment applying MAMVA-SVNS.

Step 1 . The weighted decision making matrix, which represents the evaluations of the alternatives, is constructed. Denoting the elements of the matrix by $d_{i j}, i=1,2, \ldots, m ; j=1,2, \ldots, n$ the evaluation of the $j^{\text {th }}$ alternative by the $i^{\text {th }}$ criterion, then all evaluations construct the decision matrix. The first alternative corresponds to valuated real estate asset. The other alternatives are constructed from the comparison set of the real estate assets.

Step 2. For the decision-making matrix $\bar{X}$ normalisation the linear sum approach is applied. Therefore, the elements of the matrix are determined as

$\bar{d}_{i j}=\frac{d_{i j}}{\sum_{i=1}^{m} d_{i j}} ; i=1,2, \ldots, m ; j=1,2, \ldots, n$.

Step 3. The neutrosophic conversion into the single valued neutrosophic variables is performed. A single valued neutrosophic set (SVNS) $\tilde{N} \subset X$ usually has the following form

$\tilde{N}=\left\{\left\langle x, T_{\tilde{N}}(x), I_{\tilde{N}}(x), F_{\tilde{N}}(x)\right\rangle: x \in X\right\}$

where $T_{\tilde{N}}(x): X \rightarrow[0,1], I_{\tilde{N}}(x): X \rightarrow[0,1]$ and $F_{\tilde{N}}(x): X \rightarrow[0,1]$ with $0 \leq T_{\tilde{N}}(x)+I_{\tilde{N}}(x)+F_{\tilde{N}}(x) \leq 3$ for all $x \in X$. The variables $T_{\tilde{N}}(x), I_{\tilde{N}}(x)$ and $F_{\tilde{N}}(x)$ are applied to model truth-membership degree, the indeterminacy-membership degree and the falsitymembership degree of $x$ to $\tilde{N}$, respectively. For the case when $X$ consists of the single element, $\tilde{N}$ is called a single valued neutrosophic number [33]. A single valued neutrosophic number can be denoted by $\tilde{N}_{A}=\left(t_{A}, i_{A}, f_{A}\right)$ where $t_{A}, i_{A}, f_{A} \in[0,1]$ and $0 \leq t_{A}+$ $i_{A}+f_{A} \leq 3$. In the neutrosophication step, we apply relationships between normalised terms and the single valued neutrosophic numbers. The set of normalised terms used to rate the importance of the alternatives for the decision makers is presented in Table 1.
Table 1

Conversion of the normalised terms to the single valued neutrosophic numbers.

\begin{tabular}{ll}
\hline Normalized terms & SVNNs \\
\hline 1.0 & $(1.00,0.00,0.00)$ \\
0.9 & $(0.90,0.10,0.10)$ \\
0.8 & $(0.80,0.15,0.20)$ \\
0.7 & $(0.70,0.25,0.30)$ \\
0.6 & $(0.60,0.35,0.40)$ \\
0.5 & $(0.50,0.50,0.50)$ \\
0.4 & $(0.40,0.65,0.60)$ \\
0.3 & $(0.30,0.75,0.70)$ \\
0.2 & $(0.20,0.85,0.80)$ \\
0.1 & $(0.10,0.90,0.90)$ \\
0.0 & $(0.00,1.00,1.00)$ \\
1.0 & $(1.00,0.00,0.00)$ \\
\hline
\end{tabular}
form

The single-valued decision matrix is obtained in the following

$\tilde{X}=\left[\begin{array}{llll}\tilde{x}_{11} & \tilde{x}_{12} & \ldots & \tilde{x}_{1 n} \\ \tilde{x}_{21} & \tilde{x}_{22} & \ldots & \tilde{x}_{1 n} \\ \vdots & \vdots & \ddots & \vdots \\ \tilde{x}_{m 1} & \tilde{x}_{m 2} & \ldots & \tilde{x}_{m n}\end{array}\right]$

where any particular element has the form $\tilde{x}_{i j}=\left(\tilde{t}_{i j}, \tilde{i}_{i j}, \tilde{f}_{i j}\right)$.

Step 4. Determine the weighted decision matrix. A single element of the weighted decision matrix calculated applying the following equation

$\tilde{x}_{w i j}=\left(1-\left(1-\tilde{t}_{i j}\right)^{w},\left(\tilde{i}_{i j}\right)^{w},\left(\tilde{f}_{i j}\right)^{w}\right), w>0$

where $w$ represent the weights of the criteria.

Step 5. Perform summation of the values of the criteria for the benefit. Let $L_{+}=\left\{1,2, \ldots, L_{\max }\right\}$ be a set of the criteria, which are maximised. Further, the index of the benefit for each alternative is determined

$P_{+j}=\sum_{i=1}^{L_{\max }} \tilde{x}_{w i j}^{+}$

where this summation of the single value neutrosophic numbers is performed applying the equation

$\tilde{x}_{w l} \oplus \tilde{x}_{w 2}=\left(t_{w 1}+t_{w 2}-t_{w 1} t_{w 2}, i_{w 1} i_{w 2}, f_{w 1} f_{w 2}\right)$

Step 6. Perform summation of the values of the criteria for cost. Let $L_{-}=\left\{1,2, \ldots, L_{\min }\right\}$ be a set of the criteria, which are minimised. Then the index of the cost of each alternative is calculated

$P_{-j}=\sum_{i=1}^{L_{\min }} \tilde{x}_{w i j}^{-}$

Step 7. Determine the minimal value of the $P_{-j}$.

Step 8. Determine the score measure of the each alternative $Q_{j}$. In the beginning, the score values are determined for the aggregated values for maximised and minimised criteria $S\left(P_{+j}\right)$ and $S\left(P_{-j}\right)$ applying the following expression

$S\left(\tilde{x}_{i}\right)=\frac{3+t_{i}-2 i_{i}-f_{i}}{4}$

The final score measures of the alternatives can be determined as

$Q_{j}=S\left(P_{-\min }\right)+\frac{\left(S\left(P_{-\min }\right) \sum_{j=1}^{L_{\min }} S\left(P_{-j}\right)\right)}{\left(S\left(P_{-\min }\right) \sum_{j=1}^{L_{\min }} \frac{S\left(P_{-\min }\right)}{S\left(P_{-j}\right)}\right)}$ 
Step 9. Determine optimality measure $K$ for the alternatives:

$K=\max _{j} Q_{j} ; i=1,2, \ldots, m$

Construct the priority queue of the alternatives. The greater score value $Q_{j}$ of the alternative corresponds to the highest priority (rank) of the alternative.

Step 10. Formula (11) is used for calculating utility degree $N_{j}$ :

$N_{j}=\left(Q_{j}: Q_{\max }\right) \times 100 \%$

Step 11. Determine the effectiveness degree $E_{j i}$.

In fact, the effectiveness degree $E_{j i}$ expresses the profitableness of the investment into the asset $a_{i}$ comparing to $a_{i}$ investment into the asset $a_{i} . E_{j i}$ is calculated comparing the utility degrees of the corresponding assets:

$E_{j i}=N_{j}-N_{i}$

The obtained results are represented in the form of a matrix, where the disparities of the asset utilities are clearly distinguished (see Table 5).

Step 12. For each asset an average deviation $k_{j}$ is calculated applying comparison with remaining $(n-1)$ assets:

$k_{j}=\sum_{i=2}^{n} E_{j i}:(n-1)$

Step 13. The initialization of the real estate asset valuation at the regular approximation cycle is performed as follows:

$d_{11}=\sum_{j=1}^{n} x_{1 j}: n$

The performed adjustments of the real estate asset market value are oriented to keep it close average estimation and accordingly to have a monotonic process of the approximation cycles (see Table 6).

The market value is calculated.

The adjusted real estate asset market value $d_{11-p}$ is determined as follows:

$d_{11-p}=d_{11} \times\left(1+k_{1}: 100\right)$

or

$d_{11}=\sum_{j=1}^{n} x_{1 j}: n$

The process of the approximation cycles is stopped if the adjusted value $d_{11-p}$ of asset $a_{i}$ under valuation is determined with sufficient accuracy:

$\left|k_{1}\right|<s$

where $s$ corresponds to the predefined level of accuracy of the calculation of the market value. This threshold profoundly influences the number of the approximation cycles.

When the inequality (16) is satisfied, then the market value of the asset under consideration is fixed as follows:

$d_{11-R}=d_{11-p}$

If the inequality (16) is not satisfied, then the real estate assets market value is still not adjusted to a sufficient level of accuracy, and the approximation process must be prolonged.

The obtained real estate asset market value $d_{11-R}$ is equally competitive with respect to the assets that belong to the comparison set. The neutrosophic MAMVA method is further applied to perform the market valuation of Croydon University Hospital (Emergency Department).

\section{Case study. Hospital buildings valuation by the neutrosophic MAMVA approach}

\subsection{Croydon university hospital (Emergency Department) market valuation. Initial data}

A specific example to demonstrate the neutrosophic MultiAttribute Market Value Assessment (MAMVA) is applied. The market valuation is performed at Croydon University Hospital (Emergency Department). The evaluation information of this real estate asset constructs the first alternative. Three hospital buildings $a_{2}-a_{4}$ form the comparison set for this case study. All the data come from BREEAM pre-assessment reports and other sources pertinent to Croydon University Hospital (Emergency Department) $a_{1}$ [34], Royal Shrewsbury Hospital (Future Configuration of Hospital Services) $a_{2}$ [35], Hampshire Critical Treatment Hospital $a_{3}$ [36] and Papworth Hospital $a_{4}$ [37]. Table 2 consists of criteria (BREEAM Sections and costs), their values (BREEAM Section scores and prices per square meter) and weights. The sum of the weights of all the BREEAM criteria (BREEAM Sections) is equal to 1.1. There is a comparison of the Costs criterion weight to the sum of the weights of all the other criteria (BREEAM Sections).

The evaluation results of these buildings are presented in Table 2.

The Emergency Department (ED) and Urgent Care Centre (UCC) of Croydon University Hospital will move from their current location on Mayday Road to the other side of the hospital. The hospital's doctors and nurses designed Croydon's new Emergency Department specifically to be more open-planned. This fact will offer the clinical staff a better view of their patients for improving safety and care. Croydon's new ED will be built a third larger by the highest standards using the best examples from other Emergency Departments across the country [38].

The BREEAM 2011 New Construction Preliminary Assessment Report presents the preliminary BREEAM assessment of the newly built Maternity and Pediatrics development at Royal Shrewsbury Hospital (Future Configuration of Hospital Services), which is to be constructed on the existing hospital site. The project is for the construction of a newly built, two-story infill block between two of the current nucleus templates to house Maternity and Pediatrics functions [39].

Hampshire Critical Treatment Hospital's (CTH) key elements include an Emergency Assessment Unit, Critical Care, Theatres, Maternity facilities and a midwifery led delivery unit. The vision is to develop a new and innovative model of emergency care. As such, the organization of the CTH is a "compact unit" [40]: it allows improved and streamlined patient pathways through efficient "streaming" of patients through the emergency and diagnostic departments to ensure fast and appropriate care; enhances the physical connections between staff and clinicians and between the central clinical and support departments to increase communication and increases efficiency and improves clinical pathways for the benefit of patients and staff by blurring traditional departmental boundaries. The available BREEAM scores and ratings for the project are 59.39\% Very Good [36].

Papworth Hospital has been at the forefront of heart and lung medicine ever since it transformed from a Tuberculosis (TB) sanatorium in the 1950s. The state-of-the-art, new Papworth Hospital will offer cutting-edge facilities in a building on the Cambridge Biomedical Campus. The funds for this $£ 165$ million project are from private finance and public sector funding. Moreover, a Heart and Lung Research Institute, a joint venture between Papworth Hospital and the University of Cambridge, will be built on the campus adjacent to the new hospital [41]. 
Table 2

Initial data for calculations by the MAMVA method with the additional criterion Costs.

\begin{tabular}{|c|c|c|c|c|c|c|c|}
\hline \multirow{2}{*}{$\begin{array}{l}\text { Criteria describing the } \\
\text { hospital buildings } \\
\text { (BREEAM Sections and } \\
\text { costs) }\end{array}$} & \multirow[t]{2}{*}{$*$} & \multirow{2}{*}{$\begin{array}{l}\text { Mea-suring } \\
\text { units }\end{array}$} & \multirow[t]{2}{*}{ Weight } & \multicolumn{4}{|c|}{ Compared hospital buildings (Section scores and costs) } \\
\hline & & & & $\begin{array}{l}\text { Croydon University } \\
\text { Hospital - Emergency } \\
\text { Department }\left(\mathrm{a}_{1}\right)\end{array}$ & $\begin{array}{l}\text { Royal Shrewsbury } \\
\text { Hospital - Future } \\
\text { Configuration of } \\
\text { Hospital Services }\left(\mathrm{a}_{2}\right)\end{array}$ & $\begin{array}{l}\text { Hampshire Critical } \\
\text { Treatment Hospital } \\
\left(\mathrm{a}_{3}\right)\end{array}$ & $\begin{array}{l}\text { Papworth } \\
\text { Hospital }\left(\mathrm{a}_{4}\right)\end{array}$ \\
\hline Costs & - & $£ / \mathrm{m}^{2}$ & 1.1 & 7208.28 & 4785.59 & 4705.87 & 3500 \\
\hline Management & + & $\%$ & 0.12 & 8.18 & 10.5 & 9.82 & 8.7 \\
\hline Health and wellbeing & + & $\%$ & 0.15 & 10.31 & 6.67 & 10 & 10.9 \\
\hline Energy & + & $\%$ & 0.19 & 10.64 & 5.12 & 7.6 & 9.9 \\
\hline Transport & + & $\%$ & 0.08 & 6.4 & 4.57 & 1.6 & 1.6 \\
\hline Water & + & $\%$ & 0.06 & 4.67 & 2.67 & 3.33 & 4 \\
\hline Materials & + & $\%$ & 0.125 & 8.65 & 10.83 & 8.65 & 9.6 \\
\hline Waste & + & $\%$ & 0.075 & 7.5 & 5.36 & 5 & 5 \\
\hline Land use and ecology & + & $\%$ & 0.1 & 8 & 7 & 7 & 5 \\
\hline Pollution & + & $\%$ & 0.1 & 6.92 & 5.83 & 5.38 & 6.9 \\
\hline Innovation & + & $\%$ & 0.1 & 2 & 4 & 1 & 0 \\
\hline
\end{tabular}

The sign $\ddot{+} /$ - ïndicates that a greater (lesser) criterion value corresponds to a greater (lesser) significance for a user (stakeholder).

\subsection{Croydon university hospital (Emergency Department)}

market valuation. Problem solution

By the neutrosophic MAMVA Method, the system's multiple criteria model is applied to calculate the utility degree of the considered real estate asset and the members from comparison set. Adjusting the price at which the asset under consideration would be equally competitive in the market by taking into account all criteria evaluations of the other assets, the market valuation is performed. The initial decision making matrix after the neutrosophication step is presented in Table 3 (step 1-4).

Step 5-9. Optimality criterion $K$ for the alternatives was calculated for the alternatives under analysis. Priority of the alternatives $Q_{j}$ were established based on the optimality criterion $K$. The greater the $Q_{j}$, the higher is the efficiency (priority) of the hospital alternatives (Table 4): $Q_{4} \succ Q_{2} \succ Q_{3} \succ Q_{1}$ (see Table 4:0.5592 $>0.521>$ $0.521>0.4674>0.4515$ ).

Step 10-11. Utility degree $N_{j}$ calculation by Formula (11):

$N_{1}=(0.4515: 0.5592) \times 100 \%=80.74 \%$

$N_{2}=(0.521: 0.5592) \times 100 \%=93.16 \%$

$N_{1}=(0.4674: 0.5592) \times 100 \%=83.59 \%$

$N_{1}=(0.5592: 0.5592) \times 100 \%=100 \%$

The results of a multiple criteria evaluation of sustainable hospitals under analysis versions are presented in Table 4. Table 4 shows that the fourth alternative (Papworth Hospital) is the best in the utility degree equalling $100 \%$. The second version (Royal Shrewsbury Hospital - Future Configuration of Hospital Services) was second according to priority, and its Formula (12) is used for calculating the efficiency degree $E_{j i}$ :

$$
\begin{aligned}
& E_{12}=N_{1}-N_{2}=80.74 \%-93.16 \%=-12.42 \\
& E_{13}=N_{1}-N_{3}=80.74 \%-83.59 \%=-2.85 \\
& E_{14}=N_{1}-N_{4}=80.74 \%-100 \%=-19.26 \\
& E_{21}=N_{2}-N_{1}=93.16 \%-80.74 \%=12.42 \\
& E_{23}=N_{2}-N_{3}=93.16 \%-85.59 \%=7.57
\end{aligned}
$$

$E_{24}=N_{2}-N_{4}=93.16 \%-100 \%=-6.84$

$E_{43}=N_{4}-N_{3}=100 \%-83.59 \%=16.41$

The received results are presented as a matrix clearly showing utility degree differences of the sustainable building assets (see Table 5).

Step 12. Formula (13) is used for calculating the average deviation $k_{j}$ of the utility degree $N_{j}$ of asset $a_{j}$ from the same index of another asset $(n-1)$. For example:

$$
\begin{aligned}
& k_{1}=(12.42+0+7.57+|-6.84|+2.84+|-7.57|+0+|-16.41| \\
& \quad+19.26+6.84+16.41+0): 3=10.68
\end{aligned}
$$

Step 13. The market value of the sustainable hospital project under valuation (Croydon University Hospital - Emergency Department) is calculated according to data from Table 2, the first criterion of which is based on the actual costs of the hospitals compared $\left(d_{12}=4785.59 £ / \mathrm{m}^{2}, d_{13}=4705.87 £ / \mathrm{m}^{2}\right.$ and $d_{14}=$ $\left.3500 \mathrm{f} / \mathrm{m}^{2}\right)$ and the project under valuation $\left(d_{11}=7208.28 \mathrm{f} / \mathrm{m}^{2}\right.$ (see Table 6 and Fig. 2). The first-cycle corrected value $d_{11 \text { cycle } 1}$ for the project $a_{1}$ under assessment equals the costs average of the assessed (bold font) and compared sustainable buildings see Table 6 and Fig. 2:

$d_{11 \text { cycle } 1}=(7208.28+4785.59+4705.87+3500): 4=5049.935$

The market value $\left(d_{11-R}\right)$ of the Croydon University Hospital (Emergency Department) under valuation must be determined. The formulation of this task can be the following: determine what market value $d_{11-R}$ for the Croydon University Hospital $\left(a_{1}\right)$ under valuation would be equally competitive in the market when compared with the sustainable buildings $\left(a_{2}-a_{4}\right)$ after an elaborate assessment of their positive and negative aspects. The investment costs per square meter $\left(d_{12}-d_{14}\right)$ of the other sustainable buildings $\left(a_{2}-a_{4}\right)$ under comparison are known. The decision making matrix (see Table 2), the amalgamated block diagram submitted in Fig. 2. The results of the initial approximation cycle of these calculations appear in Table 6 and Fig. 2.

Formula (15) is used for calculating the next corrected values $d_{11 \text { cyclee }}$ of the Croydon University Hospital $\mathrm{a}_{1}$ under valuation. The second-cycle corrected value $d_{11 \text { cycle } 2}$ for the project $\mathrm{a}_{1}$ under assessment equals the costs average of the first-cycle corrected 
Table 3

Initial weighted decision matrix after the neutrosophication step.

\begin{tabular}{|c|c|c|}
\hline \multirow[t]{2}{*}{ Criteria } & \multicolumn{2}{|l|}{ Alternatives } \\
\hline & Real estate asset under valuation & First real estate asset for sales comparison \\
\hline$C_{1} \min$ & $(0.3846,0.6682,0.6154)$ & $(0.2573,0.7984,0.7427)$ \\
\hline$C_{2} \max$ & $(0.0294,0.9779,0.9706)$ & $(0.0390,0.9688,0.961)$ \\
\hline$C_{3} \max$ & $(0.0465,0.963,0.9535)$ & $(0.0286,0.978,0.9714)$ \\
\hline$C_{4} \max$ & $(0.0706,0.942,0.9294)$ & $(0.0313,0.9745,0.9687)$ \\
\hline$C_{5} \max$ & $(0.0469,0.9564,0.9531)$ & $(0.0307,0.9749,0.9693)$ \\
\hline$C_{6} \max$ & $(0.0227,0.9814,0.9773)$ & $(0.012,0.9909,0.988)$ \\
\hline$C_{7} \max$ & $(0.0320,0.9756,0.968)$ & $(0.0414,0.9667,0.9586)$ \\
\hline$C_{8} \max$ & $(0.0294,0.9759,0.9706)$ & $(0.0198,0.9848,0.9802)$ \\
\hline$C_{9} \max$ & $(0.0345,0.9721,0.9655)$ & $(0.0296,0.9768,0.9704)$ \\
\hline$C_{10} \max$ & $(0.0318,0.9746,0.9682)$ & $(0.0262,0.98,0.9738)$ \\
\hline$C_{11} \max$ & $(0.0331,0.9735,0.9669)$ & $(0.0812,0.9108,0.9188)$ \\
\hline \multirow[t]{2}{*}{ Criteria } & \multicolumn{2}{|l|}{ Alternatives } \\
\hline & Second real estate asset for sales comparison & Third real estate asset for sales comparison \\
\hline$C_{1} \min$ & $(0.253,0.8007,0.747)$ & $(0.1889,0.8508,0.8111)$ \\
\hline$C_{2} \max$ & $(0.0361,0.9715,0.9639)$ & $(0.0315,0.9759,0.9685)$ \\
\hline$C_{3} \max$ & $(0.0449,0.9645,0.9551)$ & $(0.0496,0.9601,0.9504)$ \\
\hline$C_{4} \max$ & $(0.0481,0.9633,0.9519)$ & $(0.0649,0.9474,0.9351)$ \\
\hline$C_{5} \max$ & $(0.0095,0.991,0.9905)$ & $(0.0095,0.991,0.9905)$ \\
\hline$C_{6} \max$ & $(0.0153,0.9884,0.9847)$ & $(0.0189,0.985,0.9811)$ \\
\hline$C_{7} \max$ & $(0.032,0.9756,0.968)$ & $(0.036,0.9718,0.964)$ \\
\hline$C_{8} \max$ & $(0.0183,0.9862,0.9817)$ & $(0.0183,0.9862,0.9817)$ \\
\hline$C_{9} \max$ & $(0.0296,0.9768,0.9704)$ & $(0.0203,0.9847,0.9797)$ \\
\hline$C_{10} \max$ & $(0.0239,0.9821,0.9761)$ & $(0.0317,0.9747,0.9683)$ \\
\hline$C_{11} \max$ & $(0.0153,0.9871,0.9847)$ & $(0.0,1.0,1.0)$ \\
\hline
\end{tabular}

Table 4

Results of the multiple criteria analysis of the alternatives at 1st iteration.

\begin{tabular}{|c|c|c|c|c|}
\hline & $\begin{array}{l}\text { Real estate asset } \\
\text { under valuation }\end{array}$ & $\begin{array}{l}\text { First real estate } \\
\text { asset for sales } \\
\text { comparison }\end{array}$ & $\begin{array}{l}\text { Second real } \\
\text { estate asset for } \\
\text { sales comparison }\end{array}$ & $\begin{array}{l}\text { Third real estate } \\
\text { asset for sales } \\
\text { comparison }\end{array}$ \\
\hline $\begin{array}{l}\text { The sums of weighted normalised maximising } \\
\text { (project 'pluses') indices of the alternative }\end{array}$ & $(0.3197,0.7312,06803)$ & $(0.2935,0.7404,0.7065)$ & $(0.2425,0.8057,0.7575)$ & $(0.2492,0.7972,0.7508)$ \\
\hline $\begin{array}{l}\text { The sums of weighted normalised minimising } \\
\text { (project 'minuses') indices of the alternative }\end{array}$ & $(0.3846,0.6682,0.6154)$ & $(0.2573,0.7964,0.7427)$ & $(0.2530,0.8007,0.7470)$ & $(0.1889,0.8508,0.8111)$ \\
\hline Significance of the alternative & 0.4515 & 0.521 & 0.4674 & 0.5592 \\
\hline Priority of the alternative & 4 & 2 & 3 & 1 \\
\hline Utility degree of the alternative (\%) & $80.74 \%$ & $93.16 \%$ & $83.59 \%$ & $100 \%$ \\
\hline
\end{tabular}

Table 5

Calculation of average deviations of the buildings utility degrees at 1 st iteration.

\begin{tabular}{|c|c|c|c|c|c|}
\hline \multirow[t]{2}{*}{ Asset considered } & \multicolumn{4}{|c|}{$\begin{array}{l}\text { Utility degree deviation of an asset analysed } \\
\text { compared to other sustainable building, \% }\end{array}$} & \multirow{2}{*}{$\begin{array}{l}\text { Average deviation } k_{j} \text { of utility degree } \\
N_{j} \text { of asset } a_{j} \text { compared to other }(n-1) \\
\text { sustainable building, } \%\end{array}$} \\
\hline & $a_{1}$ & $a_{2}$ & $a_{3}$ & $a_{4}$ & \\
\hline$a_{1}$ & 0 & -12.42 & -2.84 & -19.26 & 11.51 \\
\hline$a_{2}$ & 12.42 & 0 & 7.57 & -6.84 & 8.93 \\
\hline$a_{3}$ & 2.84 & -7.57 & 0 & -16.41 & 8.94 \\
\hline$a_{4}$ & 19.26 & 6.84 & 16.41 & 0 & 14.17 \\
\hline
\end{tabular}

Table 6

Revised changes numerically in value and market value determinations for Croydon University Hospital ( $\left.a_{1}\right)$ under valuation.

\begin{tabular}{|c|c|c|c|c|c|c|c|}
\hline \multirow{2}{*}{$\begin{array}{l}\text { Appro-xima-tion cycle } \\
0\end{array}$} & \multirow{2}{*}{$\begin{array}{l}\text { Corrected value } x_{11-p}, \\
\left(£ / \mathrm{m}^{2}\right) \text { of } a_{1} \\
7208.28\end{array}$} & \multicolumn{5}{|c|}{$\begin{array}{l}\text { Variation of the utility degree of the hospitals Inequality 15: Calculation accuracy } k_{1 f}(\%) \text { of } \\
\text { under assessment by rationalising the the corrected value }\left(d_{11-p}\right) \text { of } a_{1} \\
\text { corrected value } d_{11-p} \text { of } a_{1} N_{1} N_{2} N_{3} N_{4}\end{array}$} & \multirow[t]{2}{*}{$\begin{array}{l}\text { Market value } \\
d_{11-R} \text {, (Euro) of } a\end{array}$} \\
\hline & & $81.2 \%$ & $90.08 \%$ & $84.05 \%$ & $100 \%$ & $\mathrm{k}_{11}=29.94 \%>1 \%$ & \\
\hline 1 & 5049.935 & $94.64 \%$ & $90.77 \%$ & $84.47 \%$ & $100 \%$ & $\mathrm{k}_{12}=10.68 \%>1 \%$ & \\
\hline 2 & 4510.3488 & $99.82 \%$ & $91.05 \%$ & $84.61 \%$ & $100 \%$ & $\mathrm{k}_{13}=2.99 \%>1 \%$ & \\
\hline \multirow[t]{2}{*}{3} & 4375.4522 & $100 \%$ & $89.96 \%$ & $83.57 \%$ & $98.73 \%$ & $0.77 \%<1 \%$ & \\
\hline & \multicolumn{7}{|c|}{$4375.4522 \times(1-0.77: 100)=4341.76 £ / \mathrm{m}^{2}$} \\
\hline
\end{tabular}




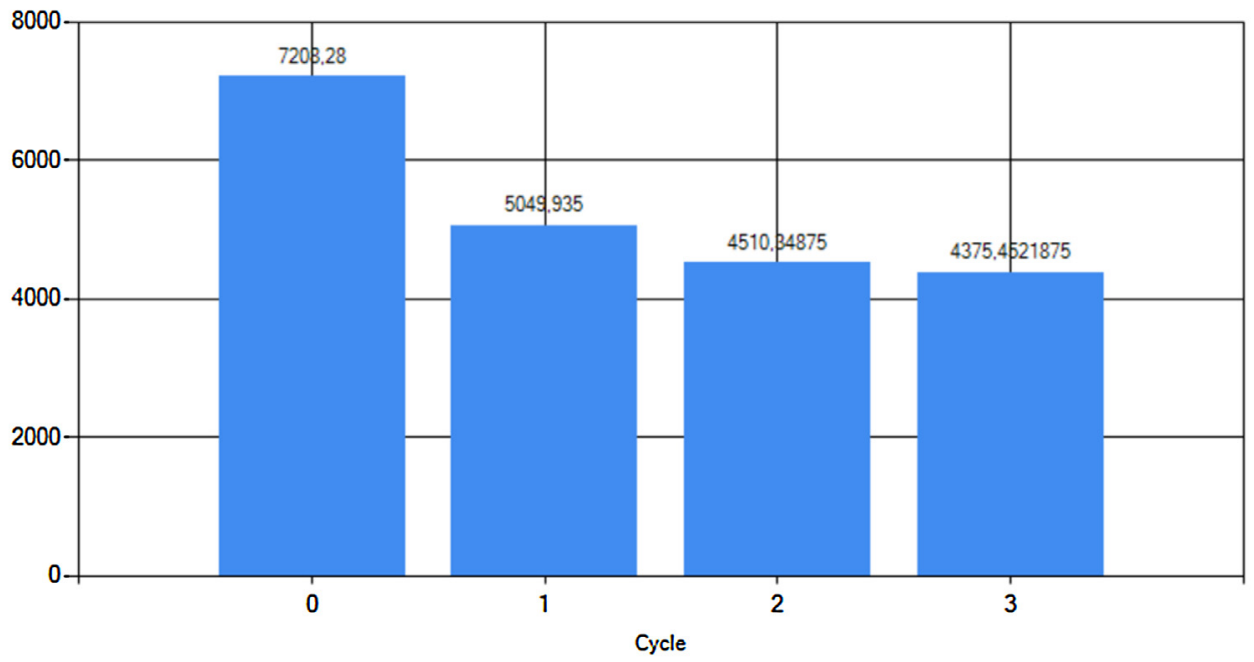

Fig. 2. Revised changes graphically in value and market value determinations for Croydon University Hospital $\left(a_{1}\right)$ under valuation.

value $d_{11 \text { cycle } 1}$ (bold font) and the original compared sustainable buildings (see Table 6 and Fig. 2):

$\mathrm{d}_{11 \text { cycle } 2}=(5049.935+4785.59+4705.87+3500): 4=4510.3488$

or

$d_{11 \text { cycle } 2}=\mathbf{5 0 4 9 . 9 3 5} \times(1-10.68502: 100)=4510.348$

The third-cycle corrected value $x_{11 \text { cycle } 3}$ for the project $\mathrm{a}_{1}$ under assessment equals the costs average of the second-cycle corrected value $d_{11 \text { cycle } 2}$ (bold font) and the original compared sustainable buildings (see Table 6 and Fig. 2):

$d_{11 \text { cycle } 3}=(4510.3488+4785.59+4705.87+3500): 4=4375.4522$

or

$d_{11 \text { cycle } 3}=\times(\mathbf{4 5 1 0} \mathbf{3 4 8 8} \times(1-2.99: 100)=4375.4893$

Inequality (16) is used for determining, whether the corrected value $d_{11 \text { cyclee }}$ of the Croydon University Hospital under valuation $\left(a_{1}\right)$ had been calculated accurately enough (see Table 6 ):

$k_{\text {accuracy } 1}=(1-5049.935: 7208.28) \times 100 \%=29.94 \%<s=0.1 \%$

$k_{\text {accuracy } 2}=(1-4510.3488: 5049.935) \times 100 \%=10.68 \%<s=0.1 \%$

$k_{\text {accuracy } 3}=(1-4375.4522: 4510.3488) \times 100 \%=2.99 \%<s=0.1 \%$

$k_{\text {accuracy } 4}=(1-4341.73: 4375.4522) \times 100 \%=0.77 \%<s=0.1 \%$

As illustrated, the desired accuracy in market value calculations for Croydon University Hospital $\left(a_{1}\right)$ was only achieved in four steps of approximation.

As Table 6 shows, the most beneficial hospital during the first cycle of approximation according to its designation for use is the Papworth Hospital $\left(a_{4}\right)\left(N_{4}=100 \%\right)$. The second most beneficial is the Croydon University Hospital $\left(a_{1}\right)$ under comparison $\left(N_{1}=94.64 \%\right)$, and then there are the third - second hospital under comparison $\left(N_{2}=90.77 \%\right)$. The calculated degrees of utility of the sustainable buildings under comparison make it apparent that the actual costsd $d_{11 \text { cycle } 0}=7208.28\left(£ / \mathrm{m}^{2}\right)$ for Croydon University Hospital $\left(a_{1}\right)$ under valuation is too high. Therefore this hospital is not equally competitive in the market as compared to the sustainable hospital under comparison, once their sets of specific positive and negative aspects have been assessed. Inequality 16 also affirms the same fact: based on this inequality (assuming, in this specific instance, that calculation accuracy $s=1 \%$ ), the determination is that the market value of $a_{1}$ has not been calculated sufficiently accurately (see Table 5):

$k_{12}=10.68 \%>1 \%$

Based on the market value of the Croydon University Hospital under valuation $\left(a_{1}\right)$, which had been calculated in the amalgamated block diagram provided in Fig. 1, the calculations cycles are continued until Inequality (15) has been satisfied. The results of these three calculations cycles show a change in the corrected value of the $a_{1}$. The determination of the market value appears in Table 6.

Table 6 shows that Inequality 16 had not been satisfied over the initial three cycles. That is the reason the value $d_{11}=d_{11-p}$ of the project $a_{1}$ under valuation, which had been revised three times (respectively $5049.935 £ / \mathrm{m}^{2}, 4510.3488 \mathrm{f} / \mathrm{m}^{2}$ and $4375.4522 \mathrm{f} / \mathrm{m}^{2}$ ), was entered into the decision making matrix (Table 2) for the multiple criteria analysis of hospitals. All the calculations by Formulae (1)-(15) were repeated until Inequality (16) was satisfied in the third cycle.

Table 6 shows that, in each following approximation cycle, the corrected value $d_{11-p}$ of $a_{1}$ under valuation was calculated more and more accurately. The determination of the market value of $a_{1}$ under valuation with respect to the other hospitals under comparison appears in the final, third approximation cycle $-N_{13 \text { cycle }}=$ $100 \%\left(N_{10 \text { cycle }}=81.2 \%, N_{11 \text { cycle }}=94.64 \%, N_{12 \text { cycle }}=99.82 \%\right) . \quad$ In the third approximation cycle the utility degree of the second project $\mathrm{a}_{2}$ under comparison, Royal Shrewsbury Hospital (Future Configuration of Hospital Services), calculates at $N_{2}=89.96 \%$. The degrees of utility for the hospitals under analysis show that the $a_{1}$ under valuation in the third approximation cycle is the more beneficial than the fourth hospital $a_{4}$ under comparison by $1.27 \%$ (100\%-98.73\%) and more beneficial than the second $a_{2}$ hospital under comparison by $10.04 \%$ (100\%-89.86\%).

Formula (17) is for calculating the market value $d_{11-R}$ of $a_{1}$ under valuation. Once Inequality (16) is satisfied, the market value of $a_{1}$ is determined.

\section{Comparison of calculated BREEAM and MAMVA scores}

To verify the reliability of calculations, the hospital scores produced by BREEAM were recalculated with MAMVA applied. The results produced by each method were then compared. 
Table 7

BREEAM score and rating calculation for Croydon University Hospital - Emergency Department [34].

\begin{tabular}{|c|c|c|c|c|c|}
\hline BREEAM Section & Credits Achieved & Credits Available & $\%$ of Credits Achieved & Section Weighting & Section Score \\
\hline Management & 15 & 22 & $68.18 \%$ & 0.12 & 8.18 \\
\hline Health \&Wellbeing & 11 & 16 & $68.75 \%$ & 0.15 & 10.31 \\
\hline Energy & 14 & 25 & $56.00 \%$ & 0.19 & 10.64 \\
\hline Transport & 8 & 10 & $80.00 \%$ & 0.08 & 6.40 \\
\hline Water & 7 & 9 & $77.78 \%$ & 0.06 & 4.67 \\
\hline Materials & 9 & 13 & $69.23 \%$ & 0.125 & 8.65 \\
\hline Waste & 6 & 6 & $100.00 \%$ & 0.075 & 7.50 \\
\hline Land Use \& Ecology & 8 & 10 & $80.00 \%$ & 0.10 & 8.00 \\
\hline Pollution & 9 & 13 & $69.23 \%$ & 0.10 & 6.92 \\
\hline Innovation & 2 & 10 & $20.00 \%$ & 0.10 & 2.00 \\
\hline Final BREEAM score & & & & 73.28 & \\
\hline BREEAM Rating & & & & Excellent & \\
\hline
\end{tabular}

Table 8

BREEAM score and rating calculation for Royal Shrewsbury Hospital - Future Configuration of Hospital Services [35].

\begin{tabular}{|c|c|c|c|c|c|}
\hline BREEAM Section & Credits Achieved & Credits Available & $\%$ of Credits Achieved & Section Weighting & Section Score \\
\hline Management & 14 & 16 & $87.50 \%$ & 0.12 & 10.50 \\
\hline Health \&Wellbeing & 8 & 18 & $44.44 \%$ & 0.15 & 6.67 \\
\hline Energy & 7 & 26 & $26.92 \%$ & 0.19 & 5.12 \\
\hline Transport & 8 & 14 & $57.14 \%$ & 0.08 & 4.57 \\
\hline Water & 4 & 9 & $44.44 \%$ & 0.06 & 2.67 \\
\hline Materials & 13 & 15 & $86.67 \%$ & 0.125 & 10.83 \\
\hline Waste & 5 & 7 & $71.43 \%$ & 0.075 & 5.36 \\
\hline Land Use \& Ecology & 7 & 10 & $70.00 \%$ & 0.10 & 7.00 \\
\hline Pollution & 7 & 12 & $58.33 \%$ & 0.10 & 5.83 \\
\hline Innovation & 4 & 10 & $40.00 \%$ & 0.10 & 4.00 \\
\hline Final BREEAM score & & & & 62.54 & \\
\hline BREEAM Rating & & & & Very Good & \\
\hline
\end{tabular}

Table 9

BREEAM score and rating calculation for Hampshire Critical Treatment Hospital [36].

\begin{tabular}{|c|c|c|c|c|c|}
\hline BREEAM Section & Credits Achieved & Credits Available & $\%$ of Credits Achieved & Section Weighting & Section Score \\
\hline Management & 18 & 22 & $81.82 \%$ & 0.12 & 9.82 \\
\hline Health \&Wellbeing & 12 & 18 & $66.67 \%$ & 0.15 & 10.00 \\
\hline Energy & 12 & 30 & $40.00 \%$ & 0.19 & 7.60 \\
\hline Transport & 2 & 10 & $20.00 \%$ & 0.08 & 1.60 \\
\hline Water & 5 & 9 & $55.56 \%$ & 0.06 & 3.33 \\
\hline Materials & 9 & 13 & $69.23 \%$ & 0.125 & 8.65 \\
\hline Waste & 4 & 6 & $66.67 \%$ & 0.075 & 5.00 \\
\hline Land Use \& Ecology & 7 & 10 & $70.00 \%$ & 0.10 & 7.00 \\
\hline Pollution & 7 & 13 & $53.85 \%$ & 0.10 & 5.38 \\
\hline Final BREEAM score & & & & 59.39 & \\
\hline BREEAM Rating & & & & Very Good & \\
\hline
\end{tabular}

Table 10

BREEAM score and rating calculation for Papworth Hospital [37].

\begin{tabular}{|c|c|c|c|c|c|}
\hline BREEAM Section & Credits Achieved & Credits Available & $\%$ of Credits Achieved & Section Weighting & Section Score \\
\hline Management & 16 & 22 & $72.73 \%$ & 0.12 & 8.7 \\
\hline Health \&Wellbeing & 16 & 22 & $72.73 \%$ & 0.15 & 10.9 \\
\hline Energy & 13 & 25 & $52.00 \%$ & 0.19 & 9.9 \\
\hline Transport & 2 & 10 & $20.00 \%$ & 0.08 & 1.6 \\
\hline Water & 6 & 9 & $66.67 \%$ & 0.06 & 4.0 \\
\hline Materials & 10 & 13 & $76.92 \%$ & 0.125 & 9.6 \\
\hline Waste & 4 & 6 & $66.67 \%$ & 0.075 & 5.0 \\
\hline Land Use \& Ecology & 5 & 10 & $50.00 \%$ & 0.10 & 5.0 \\
\hline Pollution & 9 & 13 & $69.23 \%$ & 0.10 & 6.9 \\
\hline Innovation & 0 & 10 & $72.73 \%$ & 0.10 & 0.0 \\
\hline Final BREEAM score & & & & 61.7 & \\
\hline BREEAM Rating & & & & Very Good & \\
\hline
\end{tabular}

According to Croydon University Hospital - Emergency Department BREEAM 2011 New Construction Assessment [34], the report predicts that the proposed building, with the current design intentions, has the potential to achieve a score of $73.28 \%$ e.g. BREEAM "Excellent" rating (Table 7). In Royal Shrewsbury Hospital Future Configuration of Hospital Services Design and Procurement BREEAM Assessment report [35] indicates that a score of $62.54 \%$ has been predicted which would allow the award of a BREEAM rating of "Very Good" (Table 8). Based on the BREEAM Tracker Report [36], Hampshire Critical Treatment Hospital potential scores and ratings for the project, generated at the previous stage make up 59.39\% ("Very Good") (Table 9). The results of the Papworth Hospital BREEAM New Construction 2011 pre-assessment shows that 
Table 11

Decision matrix of MAMVA method calculations for Croydon University Hospital - Emergency Department.

\begin{tabular}{|c|c|c|c|c|c|}
\hline \multirow[t]{2}{*}{ Criteria describing the alternatives } & \multirow[t]{2}{*}{$*$} & \multirow[t]{2}{*}{ Measuring units } & \multirow[t]{2}{*}{ Weight } & \multicolumn{2}{|l|}{ Compared alternatives } \\
\hline & & & & Standard: Credit Available & $\begin{array}{l}\text { Croydon University Hospital: } \\
\text { Credits Achieved }\end{array}$ \\
\hline Management & + & Credits & 0.12 & 22 & 15 \\
\hline Health and wellbeing & + & Credits & 0.15 & 16 & 11 \\
\hline Energy & + & Credits & 0.19 & 25 & 14 \\
\hline Transport & + & Credits & 0.08 & 10 & 8 \\
\hline Water & + & Credits & 0.06 & 9 & 7 \\
\hline Materials & + & Credits & 0.125 & 13 & 9 \\
\hline Waste & + & Credits & 0.075 & 6 & 6 \\
\hline Land use and ecology & + & Credits & 0.1 & 10 & 8 \\
\hline Pollution & + & Credits & 0.1 & 13 & 9 \\
\hline Innovation & + & Credits & 0.1 & 10 & 2 \\
\hline
\end{tabular}

Table 12

Decision matrix of MAMVA method calculations for Royal Shrewsbury Hospital - Future Configuration of Hospital Services.

\begin{tabular}{|c|c|c|c|c|c|}
\hline \multirow[t]{2}{*}{ Criteria describing the alternatives } & \multirow[t]{2}{*}{$*$} & \multirow[t]{2}{*}{ Measuring units } & \multirow[t]{2}{*}{ Weight } & \multicolumn{2}{|l|}{ Compared alternatives } \\
\hline & & & & Standard: Credit Available & $\begin{array}{l}\text { Royal Shrewsbury Hospital: } \\
\text { Credits Achieved }\end{array}$ \\
\hline Management & + & Credits & 0.12 & 16 & 14 \\
\hline Health and wellbeing & + & Credits & 0.15 & 18 & 8 \\
\hline Energy & + & Credits & 0.19 & 26 & 7 \\
\hline Transport & + & Credits & 0.08 & 14 & 8 \\
\hline Water & + & Credits & 0.06 & 9 & 4 \\
\hline Materials & + & Credits & 0.125 & 15 & 13 \\
\hline Waste & + & Credits & 0.075 & 7 & 5 \\
\hline Land use and ecology & + & Credits & 0.1 & 10 & 7 \\
\hline Pollution & + & Credits & 0.1 & 12 & 7 \\
\hline Innovation & + & Credits & 0.1 & 10 & 4 \\
\hline
\end{tabular}

Table 13

Decision matrix of MAMVA method calculations for Hampshire Critical Treatment Hospital.

\begin{tabular}{|c|c|c|c|c|c|}
\hline \multirow[t]{2}{*}{ Criteria describing the alternatives } & \multirow[t]{2}{*}{$*$} & \multirow[t]{2}{*}{ Measuring units } & \multirow[t]{2}{*}{ Weight } & \multicolumn{2}{|l|}{ Compared alternatives } \\
\hline & & & & Standard: Credit Available & $\begin{array}{l}\text { Hampshire Critical Treatment } \\
\text { Hospital: Credits Achieved }\end{array}$ \\
\hline Management & + & Credits & 0.12 & 22 & 18 \\
\hline Health and wellbeing & + & Credits & 0.15 & 18 & 12 \\
\hline Energy & + & Credits & 0.19 & 30 & 12 \\
\hline Transport & + & Credits & 0.08 & 10 & 2 \\
\hline Water & + & Credits & 0.06 & 9 & 5 \\
\hline Materials & + & Credits & 0.125 & 13 & 9 \\
\hline Waste & + & Credits & 0.075 & 6 & 4 \\
\hline Land use and ecology & + & Credits & 0.1 & 10 & 7 \\
\hline Pollution & + & Credits & 0.1 & 13 & 7 \\
\hline
\end{tabular}

Table 14

Decision matrix of MAMVA method calculations for Papworth Hospital.

\begin{tabular}{|c|c|c|c|c|c|}
\hline \multirow[t]{2}{*}{ Criteria describing the alternatives } & \multirow[t]{2}{*}{$*$} & \multirow[t]{2}{*}{ Measuring units } & \multirow[t]{2}{*}{ Weight } & \multicolumn{2}{|l|}{ Compared alternatives } \\
\hline & & & & Standard: Credit Available & Papworth Hospital: Credits Achieved \\
\hline Management & + & Credits & 0.12 & 22 & 16 \\
\hline Health and wellbeing & + & Credits & 0.15 & 22 & 16 \\
\hline Energy & + & Credits & 0.19 & 25 & 13 \\
\hline Transport & + & Credits & 0.08 & 10 & 2 \\
\hline Water & + & Credits & 0.06 & 9 & 6 \\
\hline Materials & + & Credits & 0.125 & 13 & 10 \\
\hline Waste & + & Credits & 0.075 & 6 & 4 \\
\hline Land use and ecology & + & Credits & 0.1 & 10 & 5 \\
\hline Pollution & + & Credits & 0.1 & 13 & 9 \\
\hline Innovation & + & Credits & 0.1 & 10 & 0 \\
\hline
\end{tabular}


Table 15

MAMVA method calculation results for Croydon University Hospital - Emergency Department.

\begin{tabular}{|c|c|c|c|c|c|}
\hline \multirow[t]{2}{*}{ Criteria describing the alternatives } & \multirow[t]{2}{*}{$*$} & \multirow[t]{2}{*}{ Measuring units } & \multirow[t]{2}{*}{ Weight } & \multicolumn{2}{|c|}{ Compared alternatives } \\
\hline & & & & $\begin{array}{l}\text { Standard: Credit } \\
\text { Available }\end{array}$ & $\begin{array}{l}\text { Croydon University Hospital: } \\
\text { Credits Achieved }\end{array}$ \\
\hline Management & + & Credits & 0.12 & 0.0714 & 0.0486 \\
\hline Health and wellbeing & + & Credits & 0.15 & 0.0889 & 0.0611 \\
\hline Energy & + & Credits & 0.19 & 0.1218 & 0.0682 \\
\hline Transport & + & Credits & 0.08 & 0.0444 & 0.0356 \\
\hline Water & + & Credits & 0.06 & 0.0338 & 0.0262 \\
\hline Materials & + & Credits & 0.125 & 0.0739 & 0.0511 \\
\hline Waste & + & Credits & 0.06 & 0.0375 & 0.0375 \\
\hline Land use and ecology & + & Credits & 0.1 & 0.0556 & 0.0444 \\
\hline Pollution & + & Credits & 0.1 & 0.0591 & 0.0409 \\
\hline Innovation & + & Credits & 0.1 & 0.0833 & 0.0167 \\
\hline $\begin{array}{l}\text { Sums of weighted, normalised, } \\
\text { maximising alternative indices } \\
\text { (project "pluses") }\end{array}$ & & & & 0.6697 & 0.4303 \\
\hline $\begin{array}{l}\text { Sums of weighted, normalised, } \\
\text { minimising alternative indices } \\
\text { (project "minuses") }\end{array}$ & & & & 0.0005 & 0.0005 \\
\hline Significance of the alternative & & & & 0.6702 & 0.4308 \\
\hline Priority of the alternative & & & & 1 & 2 \\
\hline Utility degree of the alternative (\%) & & & & $100 \%$ & $64.28 \%$ \\
\hline
\end{tabular}

Table 16

MAMVA method calculation results for Royal Shrewsbury Hospital - Future Configuration of Hospital Services.

\begin{tabular}{|c|c|c|c|c|c|}
\hline \multirow[t]{2}{*}{ Criteria describing the alternatives } & \multirow[t]{2}{*}{$*$} & \multirow[t]{2}{*}{ Measuring units } & \multirow[t]{2}{*}{ Weight } & \multicolumn{2}{|c|}{ Compared alternatives } \\
\hline & & & & $\begin{array}{l}\text { Standard: Credit } \\
\text { Available }\end{array}$ & $\begin{array}{l}\text { Royal Shrewsbury Hospital: } \\
\text { Credits Achieved }\end{array}$ \\
\hline Management & + & Credits & 0.12 & 0.064 & 0.056 \\
\hline Health and wellbeing & + & Credits & 0.15 & 0.1038 & 0.0462 \\
\hline Energy & + & Credits & 0.19 & 0.1497 & 0.0403 \\
\hline Transport & + & Credits & 0.08 & 0.0509 & 0.0291 \\
\hline Water & + & Credits & 0.06 & 0.0415 & 0.0185 \\
\hline Materials & + & Credits & 0.125 & 0.067 & 0.058 \\
\hline Waste & + & Credits & 0.06 & 0.0438 & 0.0312 \\
\hline Land use and ecology & + & Credits & 0.1 & 0.0588 & 0.0412 \\
\hline Pollution & + & Credits & 0.1 & 0.0632 & 0.0368 \\
\hline Innovation & + & Credits & 0.1 & 0.0714 & 0.0286 \\
\hline $\begin{array}{l}\text { Sums of weighted, normalised, } \\
\text { maximising alternative indices } \\
\text { (project "pluses") }\end{array}$ & & & & 0.7141 & 0.3859 \\
\hline $\begin{array}{l}\text { Sums of weighted, normalised, } \\
\text { minimising alternative indices } \\
\text { (project "minuses") }\end{array}$ & & & & 0.0005 & 0.0005 \\
\hline Significance of the alternative & & & & 0.7146 & 0.3864 \\
\hline Priority of the alternative & & & & 1 & 2 \\
\hline Utility degree of the alternative (\%) & & & & $100 \%$ & $54.07 \%$ \\
\hline
\end{tabular}

the scheme is currently sitting at 61.7\% ("Very Good") [37] (see Table 10).

For the MAMVA-based multiple criteria analysis, the available and achieved credits were compared using BREEAM's system of criteria and weights. A separate decision matrix was created for each hospital analysed. (see Table 11-14).

The input data matrices were used in MAMVA calculations. Tables 15-18 compare the standard indicators (the credits achieved are equal to credits available, i.e., all indicators are highest) and the indicators of the hospitals (Croydon University Hospital, Royal Shrewsbury Hospital, Hampshire Critical Treatment Hospital, Papworth Hospital) we analyse (the indicators of credits achieved in Tables 7-10). The significances (weights) of these BREEAM Sections (criteria) under comparison in Tables 7-10 (Section Weighting) and Table 11-14 (Weight) are identical. As seen, the data in Tables 7-10,11-14 are identical; the difference is only by the methods employed (BREEAM and MAMVA).
Tables 7-10 present the BREEAM scores. To analyse the results, we will look at the data for Croydon University Hospital as an example. The sum total of Section Weighting in Table 7 is 1.1. This means the hospital may score $110 \%\left(\mathrm{~N}_{\max }=110 \%\right)$ if its building meets the maximum BREEAM credits available. In this particular case, Croydon University Hospital scored $73.28 \%$ out of $110 \%$. The possible maximum utility degree is $100 \%$ in MAMVA calculations; the actual score for Croydon University Hospital was 64.28\% (Table 15). Whereas the BREEAM scale is 1.1 times that of MAMVA $(110 / 100=1.1)$, the score was recalculated $(64.28 \times 1.1=70.71)$, so that $\mathrm{N}_{\max }=110 \%$. Croydon University Hospital, then, scores $73.28 \%$ for BREEAM and $70.71 \%$ for MAMVA. The scores for Royal Shrewsbury Hospital and Papworth Hospital were recalculated likewise. Table 19 compares the BREEAM and MAMVA scores.

The comparison of the scores produced by BREEAM and MAMVA shows a difference of $2.57-4.89 \%$. In view of the fact that the BREEAM method makes no calculations of market value, the 
Table 17

MAMVA method calculation results for Hampshire Critical Treatment Hospital.

\begin{tabular}{|c|c|c|c|c|c|}
\hline \multirow[t]{2}{*}{ Criteria describing the alternatives } & \multirow[t]{2}{*}{$*$} & \multirow[t]{2}{*}{ Measuring units } & \multirow[t]{2}{*}{ Weight } & \multicolumn{2}{|c|}{ Compared alternatives } \\
\hline & & & & $\begin{array}{l}\text { Standard: Credit } \\
\text { Available }\end{array}$ & $\begin{array}{l}\text { Hampshire Critical Treatment } \\
\text { Hospital: Credits Achieved }\end{array}$ \\
\hline Management & + & Credits & 0.12 & 0.066 & 0.054 \\
\hline Health and wellbeing & + & Credits & 0.15 & 0.09 & 0.06 \\
\hline Energy & + & Credits & 0.19 & 0.1357 & 0.0543 \\
\hline Transport & + & Credits & 0.08 & 0.0667 & 0.0133 \\
\hline Water & + & Credits & 0.06 & 0.0386 & 0.0214 \\
\hline Materials & + & Credits & 0.125 & 0.0739 & 0.0511 \\
\hline Waste & + & Credits & 0.06 & 0.045 & 0.03 \\
\hline Land use and ecology & + & Credits & 0.1 & 0.0588 & 0.0412 \\
\hline Pollution & + & Credits & 0.1 & 0.065 & 0.0412 \\
\hline $\begin{array}{l}\text { Sums of weighted, normalized, } \\
\text { maximizing alternative indices } \\
\text { (project "pluses") }\end{array}$ & & & & 0.6397 & 0.3603 \\
\hline $\begin{array}{l}\text { Sums of weighted, normalized, } \\
\text { minimising alternative indices } \\
\text { (project "minuses") }\end{array}$ & & & & 0.0005 & 0.0005 \\
\hline Significance of the alternative & & & & 0.6402 & 0.3608 \\
\hline Priority of the alternative & & & & 1 & 2 \\
\hline Utility degree of the alternative (\%) & & & & $100 \%$ & $56.36 \%$ \\
\hline
\end{tabular}

Table 18

MAMVA method calculation results for Papworth Hospital.

\begin{tabular}{|c|c|c|c|c|c|}
\hline \multirow[t]{2}{*}{ Criteria describing the alternatives } & \multirow[t]{2}{*}{$*$} & \multirow[t]{2}{*}{ Measuring units } & \multirow[t]{2}{*}{ Weight } & \multicolumn{2}{|c|}{ Compared alternatives } \\
\hline & & & & $\begin{array}{l}\text { Standard: Credit } \\
\text { Available }\end{array}$ & $\begin{array}{l}\text { Papworth Hospital: Credits } \\
\text { Achieved }\end{array}$ \\
\hline Management & + & Credits & 0.12 & 0.0695 & 0.0505 \\
\hline Health and wellbeing & + & Credits & 0.15 & 0.0868 & 0.0632 \\
\hline Energy & + & Credits & 0.19 & 0.125 & 0.065 \\
\hline Transport & + & Credits & 0.08 & 0.0667 & 0.0133 \\
\hline Water & + & Credits & 0.06 & 0.036 & 0.024 \\
\hline Materials & + & Credits & 0.125 & 0.0707 & 0.0543 \\
\hline Waste & + & Credits & 0.06 & 0.045 & 0.03 \\
\hline Land use and ecology & + & Credits & 0.1 & 0.0667 & 0.0333 \\
\hline Pollution & + & Credits & 0.1 & 0.0591 & 0.0409 \\
\hline Innovation & + & Credits & 0.1 & 0.1 & 0 \\
\hline $\begin{array}{l}\text { Sums of weighted, normalized, } \\
\text { maximizing alternative indices } \\
\text { (project "pluses") }\end{array}$ & & & & 0.7255 & 0.3745 \\
\hline $\begin{array}{l}\text { Sums of weighted, normalized, } \\
\text { minimising alternative indices } \\
\text { (project "minuses") }\end{array}$ & & & & 0.0005 & 0.0005 \\
\hline Significance of the alternative & & & & 0.726 & 0.375 \\
\hline Priority of the alternative & & & & 1 & 2 \\
\hline Utility degree of the alternative (\%) & & & & $100 \%$ & $51.65 \%$ \\
\hline
\end{tabular}

Table 19

Calculated BREEAM and MAMVA scores compared.

\begin{tabular}{|c|c|c|c|}
\hline & $\begin{array}{l}\text { BREEAM score (maximum credits } \\
\text { achieved), \% }\end{array}$ & $\begin{array}{l}\text { MAMVA score, \% (maximum } \\
\text { utility degree) }\end{array}$ & $\begin{array}{l}\text { Difference }(\%) \text { for BREEAM and } \\
\text { MAMVA calculations }\end{array}$ \\
\hline $\begin{array}{l}\text { Croydon University Hospital - } \\
\text { Emergency Department }\end{array}$ & $73.28(110)$ & $70.71(110)$ & 2.57 \\
\hline $\begin{array}{r}\text { Royal Shrewsbury Hospital - Future } \\
\text { Configuration of Hospital Services }\end{array}$ & $62.54(110)$ & $59.49(110)$ & 3.06 \\
\hline Hampshire Critical Treatment Hospital & $59.39(100)$ & $56.36(100)$ & 3.03 \\
\hline Papworth Hospital & $61.7(110)$ & $56.81(110)$ & 4.89 \\
\hline
\end{tabular}

MAMVA method could become a new competing environmental assessment method for property market value calculations. Also, with the MAMVA method, environmental sustainability aspects may be considered in real estate market valuation.

\section{Results and conclusions}

Nowadays the aspects of the sustainability play more significant role in the in the real estate management, the real estate stakeholders must consider the impact of the real estate asset development and maintenance on the environment. Therefore, the 
environmental, social, cultural hopes of the modern society must be included into the new management paradigms. Only a few other methods (multiple criteria decision making, or MCDM, for instance), however, are used in real estate appraisal worldwide. Approved, standardized methods generally cannot produce a single optimal market value because property price statistics (type of property, property prices, area covered, property vintage, priced unit, compilation method, seasonal adjustment, etc.) is not the only element, property expert's preferences with the weights and values of the assessment criteria should also be taken into account. The neutrosophic Multi-Attribute Market Value Assessment (MAMVA) method discussed in the article and developed by its authors can determine the real market value of property incorporating sustainability aspects and also can take into account the vagueness aspects of the initial information. The MAMVA method and the sales comparison approach produced very similar market value for the same properties (a difference of up to 7\%). It could become a new competing method for property market value calculations stimulating the research knowledge onward. The MAMVA method could be a handy tool for property sellers, brokers, buyers, and lenders on regional, national and global levels. So far the MAMVA method has been applied to determine the market value of various properties (residential, commercial and retail) in Lithuania. Equivalent valuations are planned abroad in the future, and the results will be compared with those produced by the sales comparison approach and the income approach. The authors are going to develop the new extensions of MAMVA method by taking into account the new vagueness aspects of the initial information. For this purpose, we will apply the other presentations of the neutrosophic sets, such as interval, triangular neutrosophic numbers.

The MAMVA offers the new opportunities for the defining the market value of a project. Use of the MAMVA Method for the multiple criteria analysis, recommended by this article, can be for assessing sustainable buildings, the same as by the BREEAM Method. The MAMVA Method for an analysis of sustainable buildings can use the same initial data as the BREEAM Method uses. Primarily, the global innovativeness of the MAMVA method is that it determines the market value of a real estate asset under deliberation. It may be noticed that the researchers from all the world engaged in the analysis of BREEAM buildings did not calculate the market value.

\section{Acknowledgments}

The authors thank the referees for their valuable comments and suggestions, which helped to improve this paper considerably and Ms Valerija Marina for her assist in editing the English language of this text.

\section{References}

[1] J. Winkler, M. Pudlik, M. Ragwitz, B. Pfluger, The market value of renewable electricity -Which factors really matter, Appl. Energy 184 (2016) 464-481.

[2] E.C.M. Hui, K.K.K. Chan, Testing calendar effects on global securitized real estate markets by Shiryaev-Zhou index, Habitat Int. 48 (2015) 38-45.

[3] H.-C. Lin, C.-S. Wang, J.C. Chen, B. Wu, New statistical analysis in marketing research with fuzzy data, J. Bus. Res. 69 (6) (2016) 2176-2181.

[4] V. Kontrimas, A. Verikas, The mass appraisal of the real estate by computational intelligence, Appl. Soft Comput. 11 (1) (2011) 443-448.

[5] V.Zujo, D. Car-Pusic, V. Zileska-Pancovska, Cost and experience based real estate estimation model, Procedia Soc. Behav. Sci. 119 (2014) 672-681.

[6] K. Murphy, Restricted Appraisal: Multi-tenant Office building, 3111 Unicorn Lake Boulevard, City of Denton, Denton County, Texas, 2014, http://www. slideshare.net/KaylaMurphy1/appraisal-project-report, (Accessed 8 February 2016).

[7] D. Popescu, E.C. Mladin, R. Boazu, S. Bienert, Methodology for real estate appraisal of green value, Environ. Eng. Manage. J. 8 (3) (2009) 601-606.

[8] I.H. Romenesco, Real Property Appraisal Self-contained Report of Carter's Grove Historic Riverfront Estate, 8797 Pocahontas Trail, Main Residence and Dependencies on 400.532 Acres and 76.104-Acres of Vacant Land Zoned R2,
Williamsburg, James City County, Virginia 23185-6025, 2011, https://www scribd.com/document/135555870/Carters-Grove-Appraisal-May-31-2011, (Accessed 8 February 2016).

[9] S. Gill, J. Richmond, Valuation Report: Colonial Village Roseville, 3881 Eureka Road, Roseville, California 95661, 2012, https://www.sec.gov/Archives/edgar/ data/892997/000149315213002075/ex16c-i.htm, (Accessed 8 February 2016).

[10] E. Breazu, M. Ţuţui, Valuation Report: Plot of Land, Located within the Built-up Area, Location: Brasov County, Brasov City, Plot no. 1168/2, 2012, http://mayafiles.tase.co.il/RPdf/805001-806000/P805281-01.pdf, (Accessed 8 February 2016)

[11] S.H. Hawran, J.C. Malm, Approach to Value: Disposition of 946, 952 and 962 Huntington Drive, Duarte California, 2014, http://accessduarte.granicus.com/ MetaViewer.php?view_id=1\&clip_id=114\&meta_id=6541, (Accessed 8 February 2016).

[12] H.M. Moshkovich, Gomes L.F.A.M, A.I. Mechitov, An integrated multicriteria decision-making approach to real estate evaluation: case of the todim method, Pesquisa Operacional 31 (1) (2011) 3-20.

[13] A. Kaklauskas, Multiple criteria decision support of building life cycle: Research report presented for habilitation (DrSc): Technological sciences, civil engineering (02T) (1999), Vilnius Gediminas Technical University, Vilnius, Technika. $118 \mathrm{p}$

[14] L. Kanapeckiene, A. Kaklauskas, E.K. Zavadskas, S. Raslanas, Method and system for Multi-Attribute Market Value Assessment in analysis of construction and retrofit projects, Expert Syst. Appl. 38 (11) (2011) 14196-14207.

[15] O. Kettania, M. Oral, Designing and implementing a real estate appraisal system: the case of Québec Province, Canada, Soc. Econ. Plann. Sci. 49 (2015) $1-9$.

[16] M. Cupal, Historical perspective of residential development and its impact on the current market prices of apartments on the Czech real estate market, Procedia Econ Finance 26 (2015) 144-151

[17] P. Das, Revisiting the hotel capitalization rate, Int. J. Hosp. Manage. 46 (2015) $151-160$.

[18] D. Ben-Shahara, Y. Dengb, R. Sulganik, Property appraisal in high-rises: a cooperative game theory approach, J. Hous. Econ. 18 (1) (2009) 25-33.

[19] J.J. Ahn, H.W. Byun, K.J. Oh, T.Y. Kim, Using ridge regression with genetic algorithm to enhance real estate appraisal forecasting, Expert Syst. Appl. 39 (9) (2012) 8369-8379.

[20] I. Hajnal, Appraisal of work-in-progress buildings, Procedia Eng. 123 (2015) 224-232.

[21] M. İslamoğlu, M. Apan, A. Öztel, An evaluation of the financial performance of REITs in borsa istanbul: a case study using the entropy-based TOPSIS method, Int. J. Financ. Res. 6 (2) (2015) 124-136.

[22] F. Uysal, Ö. Tosun, Multi criteria analysis of the residential properties in antalya using TODIM method, Procedia Soc. Behav. Sci. 109 (2014) 322-326.

[23] L.F.A.M. Gomes, L.A.D. Rangel, An application of the TODIM method to the multicriteria rental evaluation of residential properties, Eur. J. Oper. Res. 193 (1) (2009) 204-211.

[24] A. Mardani, A. Jusoh, E.K. Zavadskas, Fuzzy multiple criteria decision-making techniques and applications-two decadesfrom 1994 to 2014, Exp. Syst. Appl. 42 (8) (2015) 4126-4148.

[25] F. Smarandache, A unifying field in logics, in: Neutrosophy: Neutrosophic Probability, Set and Logic, American Research Press, Rehoboth, USA, 1999.

[26] J. Wang, Y. Yang, L. Li, Multi-criteria decision-making method based on single valued neutrosophic linguistic Maclaurin symmetric mean operators, Neural Comput. Appl. (2016) 1-19.

[27] H. Peng, H. Zhang, J. Wang, Probability multi-valued neutrosophic sets and its application in multi-criteria group decision-making problems, Neural Comput. Appl. (2016) 1-21.

[28] R. Liang, J. Wang, L. Li, Multi-criteria group decision making method based on interdependent inputs of single valued trapezoidal neutrosophic information, Neural Comput. Appl. (2016) 1-20.

[29] Z. Tian, J. Wang, J. Wang, H. Zhang, Simplified neutrosophic linguistic multi-criteria group decision-making approach to green product development, Group Dec. Negot. (2016) 1-31.

[30] J. Peng, J. Wang, W. Yang, A multi-valued neutrosophic qualitative flexible approach based on likelihood for multi-criteria decision-making problems, Int. J. Syst. Sci. 48 (2) (2017) 425-435.

[31] H. Zhang, P. Ji, J. Wang, X. Chen, A novel decision support model for satisfactory restaurants utilizing social information: a case study of TripAdvisor.com, Tour. Manage. 59 (2017) 281-297.

[32] X. Wu, J. Wang, J. Peng, X. Chen, Cross-entropy and prioritized aggregation operator with simplified neutrosophic sets and their application in multi-criteria decision-making problems, Int. J. Fuzzy Syst. 8 (6) (2016) 1104-1116.

[33] J.J. Peng, J.Q. Wang, H.Y. Zhang, X.H. Chen, An outranking approach for multi-criteria decision-making problems with simplified neutrosophic sets, Appl. Soft Comput. 25 (2014) 336-346.

[34] D. Woosey, Croydon University Hospital - Emergency Department. BREEAM 2011 New Construction Pre-assessment Report, 2014, 63 p.

[35] H. Andrews, Royal Shrewsbury Hospital (Future Configuration of Hospital Services), Design \& Procurement BREEAM Preliminary Assessment Report, 2012, 78 p.

[36] P. Badger, Hampshire Critical Treatment Hospital. BREEAM Tracker Report. BREEAM New Construction Pre-Assessment, 2015, 37 p. 
[37] R. Tucker, Papworth Hospital - Surgical Ward and Outpatients. BREEAM New Construction Pre-assessment 13 (2013) 20 p.

[38] Croydon Health Services NHS, Changes to Croydon's Emergency Department from November as building begins on $£ 21.25 \mathrm{~m}$ new, bigger facility, 2015 ,

https://www.croydonhealthservices.nhs.uk/services/A_and_E/accident-andemergency.htm, (Accessed 8 February 2016).

[39] Shrewsbury \& Telford Hospitals NHS Trust, Design \& Procurement BREEAM Assessment, Princess Royal Hospital, Future Configuration of Hospital Services, New Build Maternity and Paediatrics, 2011, http://www.sath.nhs.uk/ Library/Documents/Future/Outline_Business_Case/APPENDIX\%20X.pdf, (Accessed 8 February 2016).
[40] Critical Treatment Hospital, Hampshire Hospitals NHS Foundation Trust, 2014, http://www.hampshirehospitals.nhs.uk/media/323145/15179_ Hampshire\%20Hospital_A1\%20Consultation\%20Boards_

FINAL\%20FULL\%20SET\%206Feb.pdf, (Accessed 8 February 2016).

[41] New Papworth Hospital, 2016, http://www.papworthhospital.nhs.uk/nph/ about-the-project, (Accessed 8 February 2016). 